\title{
REVIEW
}

\section{Cervical Lymph Node Metastasis in High-Grade Transformation of Head and Neck Adenoid Cystic Carcinoma: A Collective International Review}

\author{
Henrik Hellquist · Alena Skálová · Leon Barnes - Antonio Cardesa · Lester D. R. Thompson • \\ Asterios Triantafyllou - Michelle D. Williams • Kenneth O. Devaney • Douglas R. Gnepp • \\ Justin A. Bishop • Bruce M. Wenig • Carlos Suárez · Juan P. Rodrigo • Andrés Coca-Pelaz • \\ Primož Strojan · Jatin P. Shah · Marc Hamoir · Patrick J. Bradley · Carl E. Silver · \\ Pieter J. Slootweg • Vincent Vander Poorten • Afshin Teymoortash • Jesus E. Medina • \\ K. Thomas Robbins · Karen T. Pitman · Luiz P. Kowalski · Remco de Bree - William M. Mendenhall • \\ Jean Anderson Eloy · Robert P. Takes · Alessandra Rinaldo · Alfio Ferlito
}

To view enhanced content go to www.advancesintherapy.com Received: January 5, 2016 / Published online: February 19, 2016

(C) The Author(s) 2016. This article is published with open access at Springerlink.com

\section{ABSTRACT}

Adenoid cystic carcinoma (AdCC) is among the most common malignant tumors of the salivary glands. It is characterized by a prolonged clinical course, with frequent local recurrences,

This article was written by members and invitees of the International Head and Neck Scientific Group (https:// www.IHNSG.com).

Electronic supplementary material The online version of this article (doi:10.1007/s12325-016-0298-5) contains supplementary material, which is available to authorized users.

H. Hellquist

Department of Biomedical Sciences and Medicine, University of Algarve, Faro, Portugal

\section{A. Skálová}

Department of Pathology, Faculty of Medicine in Plzen, Charles University in Prague, Plzen, Czech Republic

L. Barnes

Department of Pathology, University of Pittsburgh

School of Medicine, Pittsburgh, PA, USA late onset of metastases and fatal outcome. High-grade transformation (HGT) is an uncommon phenomenon among salivary carcinomas and is associated with increased tumor aggressiveness. In AdCC with high-grade transformation (AdCC-HGT), the clinical course deviates from the natural history of AdCC. It tends to be accelerated, with a high propensity for lymph node metastasis. In order to shed light on this rare event and, in particular, on treatment implications, we undertook this review: searching for all published cases of AdCC-HGT. We conclude
A. Cardesa
Department of Anatomic Pathology, Hospital
Clinic, University of Barcelona, Barcelona, Spain
L. D. R. Thompson
Southern California Permanente Medical Group, Woodland Hills, CA, USA
A. Triantafyllou
Oral and Maxillofacial Pathology, School of
Dentistry, University of Liverpool and Cellular
Pathology, Liverpool Clinical Laboratories,
Liverpool, UK 
that it is mandatory to perform elective neck dissection in patients with AdCC-HGT, due to the high risk of lymph node metastases associated with transformation.

Keywords: Adenoid cystic carcinoma; Dedifferentiation; Fatal outcome; Local recurrence; High-grade transformation; Lymphatic metastasis; Neck dissection; Neoplasm recurrence; Salivary glands

\section{REVIEW}

The concept of high-grade transformation (previously also termed dedifferentiation) in neoplasms was introduced in 1971. Dahlin and Beabout [1] described a distinct entity in which a low grade chondrosarcoma was associated with a histologically high-grade sarcoma. High-grade transformation (HGT) in salivary gland tumors is rare but has been described not only in

M. D. Williams

Department of Pathology, The University of Texas

MD Anderson Cancer Center, Houston, TX, USA

K. O. Devaney

Department of Pathology, Allegiance Health,

Jackson, MI, USA

D. R. Gnepp

University Pathologists, Providence, RI, USA

D. R. Gnepp

University Pathologists, Fall River, MA, USA

\section{J. A. Bishop}

Departments of Pathology and

Otolaryngology-Head and Neck Surgery, The Johns

Hopkins Medical Institutions, Baltimore, MD, USA

B. M. Wenig

Department of Pathology, Beth Israel Medical

Center, New York, NY, USA

C. Suárez

Fundación de Investigación e Innovación

Biosanitaria del Principado de Asturias, Oviedo, Spain adenoid cystic carcinoma (AdCC) but in acinic cell carcinoma (AcCC) [2-7], polymorphous low-grade adenocarcinoma [8-10], epithelial-myoepithelial carcinoma [11-14], low-grade mucoepidermoid carcinoma [15], myoepithelial carcinoma [16], hyalinizing clear cell carcinoma $[17,18]$, and mammary analogue secretory carcinoma (MASC) [19, 20]. The molecular genetic mechanisms responsible for these transformations remain largely unknown but a few genes have been documented in HGT of salivary gland neoplasms, such as P53 gene mutation and C-MYC amplification [21-24]. HGT in salivary tumors of low-grade malignancy, such as AcCC, is associated with a higher local recurrence rate, a higher propensity for local lymph node metastasis and, a dramatic worsening of prognosis. For example, AcCC has the best prognosis of all salivary malignancies (10-year survival $\sim 90 \%$ ), but HGT in AcCC significantly reduces the mean survival of patients to 4.3 years $[5,25]$.

C. Suárez · J. P. Rodrigo

Instituto Universitario de Oncología del Principado de Asturias, University of Oviedo, Oviedo, Spain

J. P. Rodrigo - A. Coca-Pelaz

Department of Otolaryngology, Hospital

Universitario Central de Asturias, Oviedo, Spain

P. Strojan

Department of Radiation Oncology, Institute of Oncology, Ljubljana, Slovenia

J. P. Shah

Head and Neck Surgery, Memorial Sloan Kettering Cancer Center, New York, NY, USA

M. Hamoir

Department of Head and Neck Surgery, Head and Neck Oncology Program, St Luc University Hospital and King Albert II Cancer Institute, Brussels, Belgium

P. J. Bradley

Department of Otolaryngology-Head and Neck Surgery, Nottingham University Hospitals, Queens Medical Centre Campus, Nottingham, UK 
HGT in AdCC (AdCC-HGT) was first described in 1999 by Cheuk et al. [26] as "dedifferentiated adenoid cystic carcinoma" and since then more than 40 cases have been reported in the literature, most of them involving sinonasal and palatal minor glands and the submandibular glands [21, 23, 26-42]. AdCC-HGT is histologically characterized by a residual component of conventional AdCC and another distinct anaplastic cell population showing loss of the biphasic ductal and myoepithelial differentiation seen in conventional AdCC. HGT in AdCC may be apparent at the time of primary excision of the tumor or may develop in a recurrence [26]. The two components may be separate, but transitional zones can be recognized. The presence of a transitional zone may help to distinguish AdCC-HGT from a hybrid tumor in which one of the two components is an AdCC. It may also be that many of the hybrid tumors

P. J. Bradley · V. Vander Poorten

European Salivary Gland Society, Geneva, Switzerland

C. E. Silver

Departments of Surgery and Otolaryngology-Head and Neck Surgery, Albert Einstein College of Medicine, Montefiore Medical Center, Bronx, NY, USA

\section{P. J. Slootweg}

Department of Pathology, Radboud University

Medical Center, Nijmegen, The Netherlands

V. Vander Poorten

Otorhinolaryngology-Head and Neck Surgery and Department of Oncology, Section Head and Neck Oncology, University Hospitals Leuven, KU Leuven, Leuven, Belgium

\section{A. Teymoortash}

Department of Otolaryngology-Head and Neck

Surgery, Philipp University, Marburg, Germany

J. E. Medina

Department of Otorhinolaryngology, The

University of Oklahoma Health Sciences Center,

Oklahoma City, OK, USA
[43] reported in the literature represent HGT in different salivary tumors. The distinction between the solid type of AdCC and AdCC-HGT should be emphasized. The histological criteria distinguishing between the two have been outlined in 2007 by Seethala et al. [33]. The solid type of AdCC is known to have the worst prognosis of the different histological subtypes of conventional AdCCs. Distant metastasis developed in $73 \%$ of major salivary gland solid type AdCC compared to $8 \%$ and $17 \%$ in cribriform and tubular types, respectively [44]. Most reports indicate that the prognosis for patients with AdCC-HGT is even worse than for those with a solid type of AdCC [24, 33, 36] and thus its recognition is important for the individual patient. The cells in the solid type of AdCC have small hyperchromatic nuclei and a basaloid appearance; the transformed cells in AdCC-HGT have larger and more pleomorphic, vesicular nuclei. The

K. T. Robbins

Division of Otolaryngology-Head and Neck Surgery, Southern Illinois University School of Medicine, Springfield, IL, USA

K. T. Pitman

Department of Surgery, Banner MD Anderson Cancer Center, Gilbert, AZ, USA

\section{P. Kowalski}

Department of Head and Neck Surgery and Otorhinolaryngology, A. C. Camargo Cancer Center, São Paulo, Brazil

R. de Bree

Department of Head and Neck Surgical Oncology, UMC Utrecht Cancer Center, University Medical Center Utrecht, Utrecht, The Netherlands

W. M. Mendenhall

Department of Radiation Oncology, University of Florida, Gainesville, FL, USA

\section{J. A. Eloy}

Department of Otolaryngology-Head and Neck Surgery, Neurological Institute of New Jersey, Rutgers New Jersey Medical School, Newark, NJ, USA 
tubular-cribriform component of AdCC retains some of the myoepithelial immunoprofile. The conventional AdCC component in AdCC-HGT can have any mixture of growth patterns, with predominance of the cribriform and tubular patterns. The HGT component, which usually is either a poorly differentiated adenocarcinoma, or less often, an undifferentiated carcinoma, shows cells with large pleomorphic nuclei and a high mitotic rate (Fig. 1). The nuclei contain vesicular chromatin with conspicuous nucleoli. Necrosis (including comedonecrosis) is common as is a desmoplastic stroma and, tumoral calcification. Squamous areas and micropapillary growth are unique patterns seen exclusively in AdCC-HGT as compared to conventional AdCC [33]. There is an altered immunoprofile detected as a loss of the abluminal layer of myoepithelial cells [e.g. p63 and other myoepithelial/basal cell markers such as calponin, smooth muscle actin (SMA) and smooth muscle myosin heavy chain (SMMHC)], although there may be $\mathrm{S}-100$ protein expression. Ki-67 (often more than 50\%) and p53 labeling indices are often elevated while CD117 is generally lost. In some cases, cyclin D1 overexpression, as well as p53 abnormalities in association with Her-2/neu overexpression or loss of $\mathrm{pRb}$ expression, have all been detected in the AdCC-HGT component [21, 26, 30]. Studies by Seethala et al. [24] have shown C-MYC amplification in the process of HGT in AdCCs

\section{R. P. Takes}

Department of Otolaryngology-Head and Neck Surgery, Radboud University Medical Center, Nijmegen, The Netherlands

\section{A. Rinaldo}

University of Udine School of Medicine, Udine, Italy

A. Ferlito $(\square)$

Coordinator of the International Head and Neck

Scientific Group, Padua, Italy

e-mail: a.ferlito@uniud.it

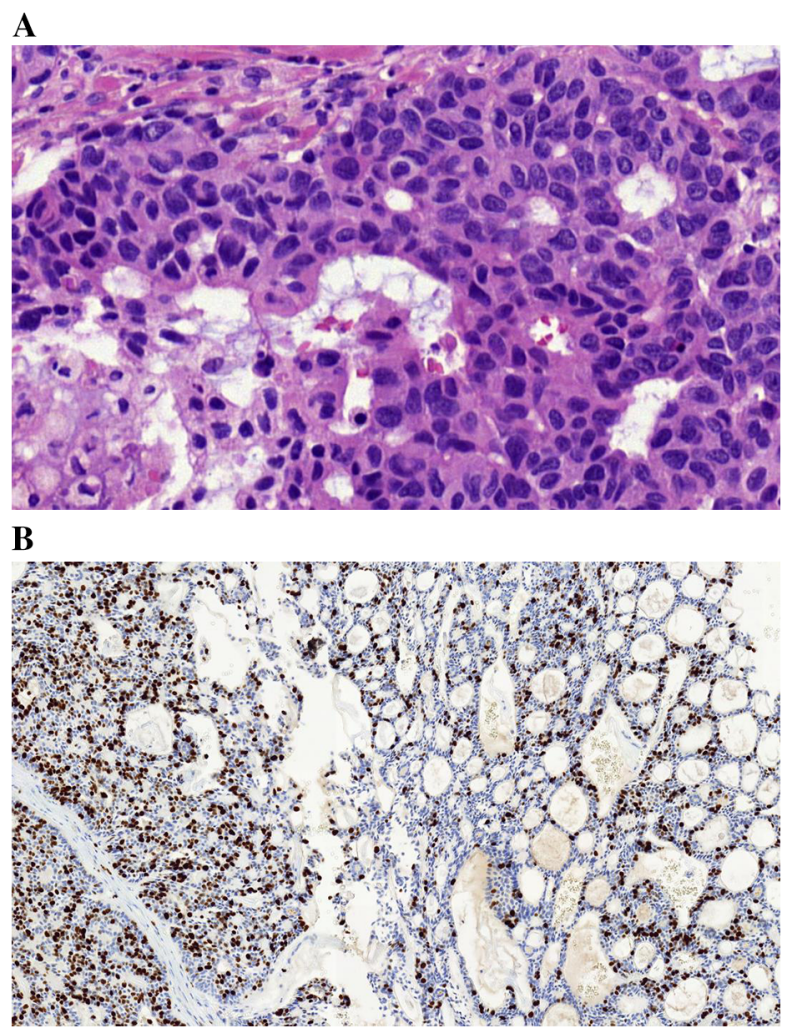

Fig. 1 High-grade transformation in adenoid cystic carcinoma (AdCC-HGT). a The transformed AdCC consists of sheets of atypical, cells and loss of architecture usually seen in a conventional AdCC. $\mathbf{b}$ AdCC-HGT with a very high labeling index with $\mathrm{Ki}-67$ (left) and a much more modest $\mathrm{Ki}-67$ index in the remnants of the conventional AdCC (right)

while other oncogenes, more frequently on chromosome 17q23, are also present, warranting further investigation. Recently, Costa et al. [45] studied 8 cases of AdCC-HGT and demonstrated that MYB/NFIB translocation is not necessarily an early event in or fundamental for the progression into AdCC-HGT.

There are statements that AdCC-HGT has a high propensity for lymph node metastasis, with as many as $57 \%$ of the patients showing metastatic disease compared to $5-25 \%$ of patients with conventional AdCC (cribriform, tubular and solid patterns) $[33,46]$. The risk for nodal disease in AdCC-HGT is likely to be 
distinctly higher when compared to conventional AdCC as many lymph nodes in cases of conventional AdCC are involved by direct extension from the primary tumor rather by a true metastasis as identified in our review of 44 cases of AdCC-HGT reported in the literature (Table 1) [21, 23, 26-42, 45, 47]. Kusafuka et al. [48] described a case of early transformation only and therefore was not included. Taking into account the possibility that some or even many of the reported hybrid tumors may represent HGT in different tumors, the number of AdCC-HGT could be even higher. Of the approximately 35 cases of hybrid tumors reviewed by Hellquist and Skalova [49], AdCC was the most common malignancy and was seen in 18 of the 33 malignant cases: two hybrid tumors comprised benign components only, and all but one of the remainder had two malignant components. The present review revealed cervical lymph node metastasis in 12 of 29 cases of AdCC-HGT. In 17 additional cases, the authors clearly stated there was no metastasis, while the remaining 15 reports did not include information about lymph node status. Thus, for the 29 cases in which information about lymph node metastasis (present or absent) was given, positive nodes were reported in 41\% (12/29). In six cases with cervical lymph node metastasis distant metastases were also reported (50\%). However synchronous or metachronous presentation could not be assessed in this review (Table 1). Seethala et al. [33] described 11 cases of AdCC-HGT where 4 of the 11 cases (36\%) had cervical lymph node metastases with multiple positive nodes and extracapsular extension in all four cases ( 5 positive nodes of $29,2 / 2,3 / 18$ and $2 / 22$ ), a percentage similar to the literature review.

In the study from the MD Anderson Cancer Center of 60 patients with early-stage (pT1, pT2)
AdCC of conventional type, seven of the 30 patients who received neck dissection had occult metastasis (23\%). This study primarily aimed to evaluate the risk for distant metastasis and survival rather than development of criteria for neck node dissection, but nevertheless, $43 \%$ of patients who had positive cervical lymph nodes after neck dissection developed distant metastasis compared to $17 \%$ who did not have positive nodes or a neck dissection. This study also demonstrated that $73 \%$ of patients with the solid subtype of conventional AdCC developed distant metastasis compared to $8 \%$ and $17 \%$ for cribriform and tubular subtypes, respectively. The subtype of AdCC among the seven patients who developed nodal disease was not specifically stated [44].

The concept of HGT in AdCC was widely accepted after the publication of Cheuk et al. [26] in 1999. There is, however, an uncertain number of reports of AdCC prior to that date, which today, according to the histological description, very likely would have been classified as AdCC-HGT. As an example, the 1985 report by Stillwagon et al. [50] would fit as AdCC-HGT: "Histologically, the tumor was an adenoid cystic carcinoma with cribriform and solid areas as well as some areas of undifferentiated carcinoma". For obvious reasons, it is impossible to review all single case reports of AdCC in the literature to document possible cases of AdCC-HGT and, therefore, only cases classified as AdCC-HGT or dedifferentiated AdCC, published after 1999 have been included in this review and are summarized in Table 1. The current review of AdCC-HGT emphatically demonstrates the importance of a very generous sampling of the surgical specimens as the HGT component may be very small. In fact, ideally the entire tumor should be sectioned and examined whenever possible. Not only will careful dissection and 
Table 1 Review of reported cases of adenoid cystic carcinoma with high-grade transformation

\begin{tabular}{|c|c|c|c|c|c|c|}
\hline $\begin{array}{l}\text { Authors } \\
\text { (year) } \\
\text { [references] }\end{array}$ & $\begin{array}{l}\text { No. } \\
\text { of } \\
\text { cases }\end{array}$ & Age & Location & $\begin{array}{l}\text { Cervical lymph } \\
\text { node } \\
\text { metastasis }\end{array}$ & Distant metastasis & $\begin{array}{l}\text { Remarks (gender, } \\
\text { tumor size, status, } \\
\text { follow-up) }\end{array}$ \\
\hline \multirow[t]{3}{*}{$\begin{array}{l}\text { Cheuk et al. } \\
\text { (1999) [26] }\end{array}$} & 3 & 55 & Tongue & Present & Bone, lung & $\begin{array}{c}\text { F, NA, DOD, } \\
15 \text { months }\end{array}$ \\
\hline & & 53 & Soft palate & Absent & Lung & F, NA, DOD, 9 months \\
\hline & & 38 & Hard palate & Present & Absent & $\begin{array}{l}\text { M, NA, DOD, } \\
18 \text { months }\end{array}$ \\
\hline $\begin{array}{l}\text { Moles et al. } \\
\text { (1999) [27] }\end{array}$ & 1 & 61 & Tongue & $\mathrm{NA}$ & NA & $\begin{array}{l}\text { M, } 3 \mathrm{~cm} \text {, NED, } \\
60 \text { months }\end{array}$ \\
\hline $\begin{array}{l}\text { Terasaki et al. } \\
(2000) \text { [28] }\end{array}$ & 1 & 49 & Lacrimal gland & $\mathrm{NA}$ & NA & F, NA, NA, NA \\
\hline $\begin{array}{l}\text { Chau et al. } \\
\qquad(2001)[21]\end{array}$ & 1 & 64 & $\begin{array}{l}\text { L submandibular } \\
\text { gland }\end{array}$ & Present & NA & $\begin{array}{c}\mathrm{F}, 3 \mathrm{~cm} \text {, NED, } \\
6 \text { months }\end{array}$ \\
\hline $\begin{array}{l}\text { Ide et al. } \\
\text { (2003) [29] }\end{array}$ & 1 & 62 & Soft palate & NA & NA & $\mathrm{M}, 2.2 \mathrm{~cm}, \mathrm{NA}, \mathrm{NA}$ \\
\hline \multirow[t]{6}{*}{$\begin{array}{l}\text { Nagao et al. } \\
(2003)[30]\end{array}$} & 6 & 55 & $\mathrm{~L}$ maxillary sinus & Present & Bone, lung & $\begin{array}{l}\mathrm{F}, 6.0 \mathrm{~cm}, \mathrm{DOD}, \\
6 \text { months }\end{array}$ \\
\hline & & 51 & $\begin{array}{l}\mathrm{R} \text { submandibular } \\
\text { gland }\end{array}$ & Absent & Bone & $\begin{array}{l}\mathrm{M}, 4.5 \mathrm{~cm}, \mathrm{DOD}, \\
24 \text { months }\end{array}$ \\
\hline & & 35 & L nasal cavity & Absent & Absent & $\begin{array}{l}\mathrm{F}, 1.8 \mathrm{~cm}, \mathrm{DOD}, \\
36 \text { months }\end{array}$ \\
\hline & & 70 & $\begin{array}{l}\mathrm{R} \text { submandibular } \\
\text { gland }\end{array}$ & Present & Absent & $\begin{array}{l}\mathrm{M}, 3.5 \mathrm{~cm}, \mathrm{DOD}, \\
69 \text { months }\end{array}$ \\
\hline & & 34 & $\mathrm{R}$ maxillary sinus & Present & Absent & $\begin{array}{c}\text { F, NA, AWD, } \\
60 \text { months }\end{array}$ \\
\hline & & 36 & L nasal cavity & Absent & Bone, lung & $\mathrm{M}, 1.7 \mathrm{~cm}, \mathrm{DOD}, \mathrm{NA}$ \\
\hline $\begin{array}{l}\text { Brackrock } \\
\text { et al. (2005) } \\
{[31]}\end{array}$ & 1 & NA & NA & $\mathrm{NA}$ & NA & $\begin{array}{l}\text { HGT first after } \\
\text { radiotherapy }\end{array}$ \\
\hline $\begin{array}{l}\text { Sato et al. } \\
\qquad(2006)[32]\end{array}$ & 1 & 74 & $\mathrm{R}$ maxillary sinus & Absent & $\begin{array}{l}\text { Lung, liver, spleen, bone, } \\
\text { pulmonaryhilar lymph } \\
\text { nodes }\end{array}$ & $\begin{array}{l}\mathrm{M}, 4 \mathrm{~cm}, \mathrm{DOD} \\
4 \text { months }\end{array}$ \\
\hline
\end{tabular}


Table 1 continued

\begin{tabular}{|c|c|c|c|c|c|c|}
\hline $\begin{array}{l}\text { Authors } \\
\text { (year) } \\
\text { [references] }\end{array}$ & $\begin{array}{l}\text { No. } \\
\text { of } \\
\text { cases }\end{array}$ & Age & Location & $\begin{array}{l}\text { Cervical lymph } \\
\text { node } \\
\text { metastasis }\end{array}$ & Distant metastasis & $\begin{array}{l}\text { Remarks (gender, } \\
\text { tumor size, status, } \\
\text { follow-up) }\end{array}$ \\
\hline \multirow{11}{*}{$\begin{array}{l}\text { Seethala et al. } \\
\qquad(2007)[33]\end{array}$} & \multirow[t]{11}{*}{11} & 72 & $\mathrm{R}$ maxillary sinus & NA & NA & $\mathrm{M}, \mathrm{NA}, \mathrm{NA}, \mathrm{NA}$ \\
\hline & & 59 & Pterygopalatine & Absent & Absent & $\begin{array}{l}\text { M, NA, DOD, } \\
12 \text { months }\end{array}$ \\
\hline & & 57 & $\mathrm{R}$ submandibular & Present & Lung & $\begin{array}{l}\mathrm{M}, 7 \mathrm{~cm}, \mathrm{DOD} \\
15 \text { months }\end{array}$ \\
\hline & & 53 & L nasal & Absent & Lung & $\begin{array}{l}\mathrm{F}, 4 \mathrm{~cm}, \mathrm{DOD} \\
12 \text { months }\end{array}$ \\
\hline & & 62 & $\mathrm{R}$ submandibular & Present & NA & $\begin{array}{c}\mathrm{F}, 1.7 \mathrm{~cm} \text {, Alive, } \\
48 \text { months }\end{array}$ \\
\hline & & 61 & $\mathrm{R}$ paranasal sinus & NA & NA & $\begin{array}{l}\text { F, NA, Dead, } \\
44 \text { months }\end{array}$ \\
\hline & & 66 & $\mathrm{R}$ pyriform & Absent & NA & $\begin{array}{l}\text { M, } 7 \mathrm{~cm} \text {, Dead, } \\
8 \text { months }\end{array}$ \\
\hline & & 32 & Maxillary & Present & NA & $\mathrm{M}, 6 \mathrm{~cm}, \mathrm{NA}, \mathrm{NA}$ \\
\hline & & 64 & $\mathrm{R}$ palate & Absent & NA & $\begin{array}{l}\mathrm{F}, 2.7 \mathrm{~cm}, \mathrm{AWD}, \\
1 \mathrm{month}\end{array}$ \\
\hline & & 42 & $\mathrm{R}$ submandibular & Present & Soft tissue & $\begin{array}{l}\mathrm{M}, 3 \mathrm{~cm}, \mathrm{AWD}, \\
3 \text { months }\end{array}$ \\
\hline & & 66 & $\mathrm{R}$ submandibular & Absent & Absent & $\begin{array}{l}\mathrm{M}, 2 \mathrm{~cm} \text {, Alive, } \\
2 \text { months }\end{array}$ \\
\hline $\begin{array}{l}\text { Handra-Luca } \\
\text { et al. (2009) } \\
{[34]}\end{array}$ & 1 & 51 & Maxillary sinus & NA & Lung & F, NA, NA, NA \\
\hline $\begin{array}{l}\text { Malhotra et al. } \\
\qquad(2009)[35]\end{array}$ & 1 & 54 & $\mathrm{R}$ parotid & NA & Absent & $\begin{array}{l}\text { M, } 5 \mathrm{~cm}, \mathrm{NED}, \\
5 \text { months }\end{array}$ \\
\hline \multirow{7}{*}{$\begin{array}{r}\text { Bonfitto et al. } \\
(2010)[23]\end{array}$} & \multirow[t]{7}{*}{7} & 44 & Submandibular & Absent & Absent & F, T2, NA, 18 months \\
\hline & & 55 & Palate & Absent & Absent & $\begin{array}{l}\text { F, T4, NED, } \\
140 \text { months }\end{array}$ \\
\hline & & 65 & Paranasal sinus & Absent & Absent & M, T4, Dead, 8 months \\
\hline & & 49 & Parotid & Absent & Liver & F, T3, Alive, 33 months \\
\hline & & 64 & Submandibular & Present & Liver & F, T2, DOD, 7 months \\
\hline & & 58 & Lips & Absent & Absent & F, T2, NED, 18 months \\
\hline & & 47 & Palate & Present $^{\mathrm{a}}$ & Lung & $\begin{array}{c}\text { M, T4, Alive, } \\
12 \text { months }\end{array}$ \\
\hline
\end{tabular}


Table 1 continued

\begin{tabular}{|c|c|c|c|c|c|c|}
\hline $\begin{array}{l}\text { Authors } \\
\text { (year) } \\
\text { [references] }\end{array}$ & $\begin{array}{l}\text { No. } \\
\text { of } \\
\text { cases }\end{array}$ & Age & Location & $\begin{array}{l}\text { Cervical lymph } \\
\text { node } \\
\text { metastasis }\end{array}$ & Distant metastasis & $\begin{array}{l}\text { Remarks (gender, } \\
\text { tumor size, status, } \\
\text { follow-up) }\end{array}$ \\
\hline $\begin{array}{l}\text { Costa et al. } \\
\qquad(2011)^{b}[36]\end{array}$ & 1 & 61 & Paranasal sinus & NA & Absent & $\begin{array}{l}\text { F, T2, Alive, } \\
144 \text { months }\end{array}$ \\
\hline $\begin{array}{l}\text { Panarelli et al. } \\
\qquad(2011) \text { [37] }\end{array}$ & 1 & 52 & Lacrimal gland & NA & NA & $\begin{array}{l}\mathrm{M}, 3.2 \mathrm{~cm}, \mathrm{AWD} \\
12 \text { months }\end{array}$ \\
\hline \multirow[t]{3}{*}{$\begin{array}{l}\text { Boland et al. } \\
\text { (2012) [38] }\end{array}$} & 3 & 61 & Parotid & NA & NA & $\begin{array}{l}\text { F, NA, Alive, } \\
169 \text { months }\end{array}$ \\
\hline & & 56 & Parotid & NA & NA & $\begin{array}{l}\text { M, NA, ANED, } \\
77 \text { months }\end{array}$ \\
\hline & & 40 & Submandibular & NA & NA & $\begin{array}{l}\text { M, NA, ANED, } \\
6 \text { months }\end{array}$ \\
\hline $\begin{array}{l}\text { Argyris et al. } \\
\text { (2013) [39] }\end{array}$ & 1 & 39 & Lacrimal gland & NA & NA & $\begin{array}{l}\mathrm{F}, 3 \mathrm{~cm}, \mathrm{AWD} \\
24 \text { months }\end{array}$ \\
\hline $\begin{array}{l}\text { Bayle et al. } \\
\qquad(2013)[40]\end{array}$ & 1 & 45 & Palate & NA & NA & $\mathrm{F}, 4.5 \mathrm{~cm}, \mathrm{NA}, \mathrm{NA}$ \\
\hline $\begin{array}{l}\text { Ly et al. } \\
\qquad(2013)[41]\end{array}$ & 1 & 88 & Parotid & Absent & Absent & $\begin{array}{c}\mathrm{F}, 3 \mathrm{~cm} \text {, Alive, } \\
12 \text { months }\end{array}$ \\
\hline $\begin{array}{l}\text { Sayar et al. } \\
\qquad(2013)[42]\end{array}$ & 1 & 39 & $\begin{array}{l}\text { L submandibular } \\
\text { gland }\end{array}$ & Absent & NA & $\begin{array}{l}\mathrm{F}, 4.0 \mathrm{~cm}, \mathrm{NED}, \\
36 \text { months }\end{array}$ \\
\hline \multirow{10}{*}{$\begin{array}{r}\text { Total Data } \\
\text { Available }\end{array}$} & 44 & 54.4 & 2 Tongue & 17 Absent & 13 Absent & \\
\hline & & & 7 Palate & 12 Present & 13 Present & \\
\hline & & & 3 Lacrimal gland & $15 \mathrm{NA}$ & $18 \mathrm{NA}$ & \\
\hline & & & 11 & & & \\
\hline & & & Submandibular & & & \\
\hline & & & 9 Paranasal sinus & & & \\
\hline & & & 3 Nasal cavity & & & \\
\hline & & & 5 Parotid & & & \\
\hline & & & 3 Other & & & \\
\hline & & & $1 \mathrm{NA}$ & & & \\
\hline
\end{tabular}

Alive alive (no further information), $A N E D$ alive with no evidence of disease, $A W D$ alive with disease, Dead dead (no further information), $D O D$ dead of disease, $F$ female, $H G T$ high-grade transformation, $L$ left, $M$ male, $N A$ information not available, $N E D$ no evidence of disease, $N o$ number, $R$ right

a A later study by Costa et al. in 2012 [47] and another one in 2014 [45] comprised 8 cases; 7 of the cases derived from the 2010 study by Bonfitto et al. [23] and the additional 8th case from the 2011 study by Costa et al. [36]. In the 2014 study by Costa et al. [45], it is stated that this same particular palatal tumor did not have any cervical lymph node metastasis

b In the 2011 study, Costa et al. [36] reported 6 cases of AdCC-HGT, however, 5 of the cases were included in the previous 2010 study by Bonfitto et al. [23]; hence only one new case presented in this 2011 study by Costa et al. [36] 
histologic evaluation help to identify any possible focus of HGT, but may also highlight areas of solid subtype in a conventional AdCC.

\section{CONCLUSION}

Based on the literature review, lymph node metastasis may occur in $43-57 \%$ of patients with AdCC-HGT. This high propensity for lymph node metastases, which is at least 5-10 times higher than for conventional AdCC, strongly supports the use of neck dissection for patients with this unique histology. Preoperative staging workup is mandatory due to the high risk of distant metastasis. In situations where such histology is not recognized until after extirpative surgery for the primary, it appears justified to subsequently include the neck electively in the post-operative radiotherapy or perform a postoperative elective neck dissection (if distant metastasis are ruled out) followed by adjuvant radiation therapy to the primary site and the regional lymph nodes.

\section{ACKNOWLEDGMENTS}

No funding or sponsorship was received for this study or publication of this article. All named authors meet the International Committee of Medical Journal Editors (ICMJE) criteria for authorship for this manuscript, take responsibility for the integrity of the work as a whole, and have given final approval for the version to be published.

Disclosures. Henrik Hellquist, Alena Skálová, Leon Barnes, Antonio Cardesa, Lester D. R. Thompson, Asterios Triantafyllou, Michelle D. Williams, Kenneth O. Devaney, Douglas R. Gnepp, Justin A. Bishop, Bruce M. Wenig, Carlos Suárez, Juan P. Rodrigo, Andrés
Coca-Pelaz, Primož Strojan, Jatin P. Shah, Marc Hamoir, Patrick J. Bradley, Carl E. Silver, Pieter J. Slootweg, Vincent Vander Poorten, Afshin Teymoortash, Jesus E. Medina, K. Thomas Robbins, Karen T. Pitman, Luiz P. Kowalski, Remco de Bree, William M. Mendenhall, Jean Anderson Eloy, Robert P. Takes, Alessandra Rinaldo and Alfio Ferlito have nothing to disclose.

Compliance with Ethics Guidelines. This article is based on previously conducted studies and does not involve any new studies of human or animal subjects performed by any of the authors.

Open Access. This article is distributed under the terms of the Creative Commons Attribution-NonCommercial 4.0 International License (http://creativecommons.org/licenses/ by-nc/4.0/), which permits any noncommercial use, distribution, and reproduction in any medium, provided you give appropriate credit to the original author(s) and the source, provide a link to the Creative Commons license, and indicate if changes were made.

\section{REFERENCES}

1. Dahlin DC, Beabout JW. Dedifferentiation of low-grade chondrosarcomas. Cancer. 1971;28:461-6.

2. Stanley RJ, Weiland LH, Olsen KD, Pearson BW. Dedifferentiated acinic cell (acinous) carcinoma of the parotid gland. Otolaryngol Head Neck Surg. 1988;98:155-61.

3. Henley JD, Geary WA, Jackson CL, Wu CD, Gnepp DR. Dedifferentiated acinic cell carcinoma of the parotid gland: a distinct rarely described entity. Hum Pathol. 1997;28:869-73.

4. Di Palma S, Corletto V, Lavarino C, Birindelli S, Pilotti S. Unilateral aneuploid dedifferentiated acinic cell carcinoma associated with bilateral low 
grade diploid acinic cell carcinoma of the parotid gland. Virchows Arch. 1999;434:361-5.

5. Skálová A, Sima R, Vanecek T, Muller S, Korabecna M, Nemcova J, Elmberger G, Leivo I, Passador-Santos F, Walter J, Rousarova M, Jedlickova K, Curik R, Geierova M, Michal M. Acinic cell carcinoma with high-grade transformation: a report of 9 cases with immunohistochemical study and analysis of TP53 and HER-2/neu genes. Am J Surg Pathol. 2009;33:1137-45.

6. Ilayaraja V, Prasad H, Anuthama K, Sruthi R. Acinic cell carcinoma of minor salivary gland showing features of high-grade transformation. J Oral Maxillofac Pathol. 2014;18:97-101.

7. Thompson LD, Aslam MN, Stall JN, Udager AM, Chiosea S, McHugh JB (2015) Clinicopathologic and immunophenotypic characterization of 25 cases of acinic cell carcinoma with high-grade transformation. Head Neck Pathol [Epub ahead of print].

8. Lloreta J, Serrano S, Corominas JM, Ferrés-Padró E. Polymorphous low-grade adenocarcinoma arising in the nasal cavities with an associated undifferentiated carcinoma. Ultrastruct Pathol. 1995;19:365-70.

9. Pelkey TJ, Mills SE. Histologic transformation of polymorphous low-grade adenocarcinoma of salivary gland. Am J Clin Pathol. 1999;111:785-91.

10. Simpson RH, Pereira EM, Ribeiro AC, Abdulkadir A, Reis-Filho JS. Polymorphous low-grade adenocarcinoma of the salivary glands with transformation to high-grade carcinoma. Histopathology. 2002;41:250-9.

11. Alos L, Carrillo R, Ramos J, Baez JM, Mallofre C, Fernandez PL, Cardesa A. High-grade carcinoma component in epithelial-myoepithelial carcinoma of salivary glands clinicopathological, immunohistochemical and flow-cytometric study of three cases. Virchows Arch. 1999;434:291-9.

12. Seethala RR, Barnes EL, Hunt JL. Epithelial-myoepithelial carcinoma: a review of the clinicopathologic spectrum and immunophenotypic characteristics in 61 tumors of the salivary glands and upper aerodigestive tract. Am J Surg Pathol. 2007;31:44-57.

13. Kusafuka K, Takizawa Y, Ueno T, Ishiki H, Asano R, Kamijo T, Iida Y, Ebihara M, Ota Y, Onitsuka T, Kameya T. Dedifferentiated epithelial-myoepithelial carcinoma of the parotid gland: a rare case report of immunohistochemical analysis and review of the literature. Oral Surg Oral Med Oral Pathol Oral Radiol Endod. 2008;106:85-91.
14. Roy P, Bullock MJ, Perez-Ordoñez B, Dardick I, Weinreb I. Epithelial-myoepithelial carcinoma with high grade transformation. Am J Surg Pathol. 2010;34:1258-65.

15. Nagao T, Gaffey TA, Kay PA, Unni KK, Nascimento AG, Sebo TJ, Serizawa $H$, Minato $H$, Lewis JE. Dedifferentiation in low-grade mucoepidermoid carcinoma of the parotid gland. Hum Pathol. $2003 ; 34: 1068-72$.

16. Ogawa I, Nishida T, Miyauchi M, Sato S, Takata T. Dedifferentiated malignant myoepithelioma of the parotid gland. Pathol Int. 2003;53:704-9.

17. O'Regan E, Shandilya M, Gnepp DR, Timon C, Toner M. Hyalinizing clear cell carcinoma of salivary gland: an aggressive variant. Oral Oncol. 2004;40:348-52.

18. Jin R, Craddock KJ, Irish JC, Perez-Ordonez B, Weinreb I. Recurrent hyalinizing clear cell carcinoma of the base of tongue with high-grade transformation and EWSR1 gene rearrangement by FISH. Head Neck Pathol. 2012;6:389-94.

19. Skálová A, Vanecek T, Majewska H, Laco J, Grossmann P, Simpson RHW, Hauer L, Andrle P, Hosticka L, Branžovský J, Michal M. Mammary analogue secretory carcinoma of salivary glands with high grade transformation: report of three cases with the ETV6-NTRK3 gene fusion and analysis of TP53, beta-catenin, EGFR and CCND1 genes. Am J Surg Pathol. 2014;38:23-33.

20. Luo W, Lindley SW, Lindley PH, Krempl GA, Seethala RR, Fung K-M. Mammary analog secretary carcinoma of salivary gland with high-grade histology arising in hard palate, report of a case and review of the literature. Int J Clin Exp Pathol. 2014;7:9008-22.

21. Chau Y, Hongyo T, Aozasa K, Chan JK. Dedifferentiation of adenoid cystic carcinoma: report of a case implicating p53 gene mutation. Hum Pathol. 2001;32:1403-7.

22. Subramaniam MM, Ng SB, Seah SB, Anuar D, Soong $\mathrm{R}$, Lee VK. Molecular characterization of dedifferentiated mucoepidermoid carcinoma of the trachea using laser microdissection-based TP53 mutation analysis. Histopathology. 2009;55:472-5.

23. Bonfitto VL, Demasi AP, Costa AF, Bonfitto JF, Araujo VC, Altemani A. High-grade transformation of adenoid cystic carcinomas: a study of the expression of GLUT1 glucose transporter and of mitochondrial antigen. J Clin Pathol. 2010;63:615-9.

24. Seethala RR, Cieply K, Barnes EL, Dacic S. Progressive genetic alterations of adenoid cystic 
carcinoma with high-grade transformation. Arch Pathol Lab Med. 2011;135:123-30.

25. Hellquist $H$, Skálová A. High grade transformation in salivary gland neoplasms. Histopathology of the salivary glands. Heidelberg: Springer; 2014. p. 432-4.

26. Cheuk W, Chan JKC, Ngan RKC. Dedifferentiation in adenoid cystic carcinoma of salivary gland. An uncommon complication associated with an accelerated clinical course. Am J Surg Pathol. 1999;23:465-72.

27. Moles MA, Avila IR, Archila AR. Dedifferentiation occurring in adenoid cystic carcinoma of the tongue. Oral Surg Oral Med Oral Pathol Oral Radiol Endod. 1999;88:177-80.

28. Terasaki M, Tokutomi T, Maruiwa H, Sugita Y, Harada H, Shigemori M. High-grade adenoid cystic carcinoma originating from the lacrimal gland. Brain Tumor Pathol. 2000;17:159-63.

29. Ide F, Mishima K, Saito I. Small foci of high-grade carcinoma cells in adenoid cystic carcinoma represent an incipient phase of dedifferentiation. Histopathology. 2003;43:604-6.

30. Nagao T, Gaffey TA, Serizawa H, Sugano I, Ishida Y, Yamazaki K, Tokashiki R, Yoshida T, Minato H, Kay PA, Lewis JE. Dedifferentiated adenoid cystic carcinoma: a clinicopathologic study of 6 cases. Mod Pathol. 2003;16:1265-72.

31. Brackrock S, Krüll A, Röser K, Schwarz R, Riethdorf L, Alberti W. Neutron therapy, prognostic factors and dedifferentiation of adenoid cystic carcinomas (ACC) of salivary glands. Anticancer Res. 2005;25:1321-6.

32. Sato K, Ueda Y, Sakurai A, Ishikawa Y, Kaji S, Nojima T, Katsuda S. Adenoid cystic carcinoma of the maxillary sinus with gradual histologic transformation to high-grade adenocarcinoma: a comparative report with dedifferentiated carcinoma. Virchows Arch. 2006;448:204-8.

33. Seethala RR, Hunt JL, Baloch ZW, Livolsi VA, Barnes EL. Adenoid cystic carcinoma with high-grade transformation: a report of 11 cases and a review of the literature. Am J Surg Pathol. 2007;31:1683-94.

34. Handra-Luca A, Planchard D, Fouret P. Docetaxel-cisplatin-radiotherapy in adenoid cystic carcinoma with high-grade transformation. Oral Oncol. 2009;45:e208-9.

35. Malhotra KP, Agrawal V, Pandey R. High grade transformation in adenoid cystic carcinoma of the parotid: report of a case with cytologic, histologic and immunohistochemical study. Head Neck Pathol. 2009;3:310-4.
36. Costa AF, Altemani A, Vékony $\mathrm{H}$, Bloemena $\mathrm{E}$, Fresno F, Suárez C, Llorente JL, Hermsen M. Genetic profile of adenoid cystic carcinomas (ACC) with high grade transformation versus solid type. Cell Oncol. 2011;34:369-79.

37. Panarelli JF, Zoumalan CI, Mukkamala K, Maher EA, Iacob C, Della Rocca DA. Dedifferentiated adenoid cystic carcinoma of the lacrimal gland. Ophthal Plast Reconstr Surg. 2011;27:e119-21.

38. Boland JM, McPhail ED, García JJ, Lewis JE, Schembri-Wismayer DJ. Detection of human papilloma virus and p16 expression in high-grade adenoid cystic carcinoma of the head and neck. Mod Pathol. 2012;25:529-36.

39. Argyris PP, Pambuccian SE, Cayci Z, Singh C, Tosios KI, Koutlas IG. Lacrimal gland adenoid cystic carcinoma with high-grade transformation to myoepithelial carcinoma: report of a case and review of the literature. Head Neck Pathol. $2013 ; 7: 85-92$.

40. Bayle RM, D'Mello S, Makaria S, Hosthor SS. Dedifferentiation in adenoid cystic carcinoma. J Oral Maxillofac Pathol. 2013;17:474-7.

41. Ly CK, Cheng HM, Vermeulen T. High grade transformation in a case of adenoid cystic carcinoma associated with Epstein-Barr virus expression. Pathology. 2013;45:693-5.

42. Sayar H, Sarioğlu S, Bakaris S, Yildirim I, Öztarakçi. High-grade transformation of adenoid cystic carcinoma delineated with a fibrous rim: a case report. Balkan Med J. 2013;30:333-6.

43. Seifert G, Donath K. Hybrid tumours of salivary glands. Definition and classification of five rare cases. Eur J Cancer B Oral Oncol. 1996;32:251-9.

44. Bhayani MK, Yener M, El-Naggar A, Garden A, Hanna EY, Weber RS, Kupferman ME. Prognosis and risk factors for early-stage adenoid cystic carcinoma of the major salivary glands. Cancer. 2012;118:2872-8.

45. Costa AF, Altemani A, García-Inclán C, Fresno F, Suárez C, Llorente JL, Hermsen M. Analysis of MYB oncogene in transformed adenoid cystic carcinomas reveals distinct pathways of tumor progression. Lab Invest. 2014;94:692-702.

46. Nagao T. "Dedifferentiation" and high-grade transformation in salivary gland carcinomas. Head Neck Pathol. 2013;7:37-47.

47. Costa AF, Tasso MG, Mariano FV, Soares AB, Chone CT, Crespo AN, Fresno MF, Llorente JL, Suárez C, de Araújo VC, Hermsen M, Altemani A. Levels and patterns of expression of hypoxia-inducible 
factor-1 $\alpha$, vascular endothelial growth factor, glucose transporter-1 and CD105 in adenoid cystic carcinomas with high-grade transformation. Histopathology. 2012;60:816-25.

48. Kusafuka K, Miki T, Nakajima T. Salivary adenoid cystic carcinoma with an early phase of high-grade transformation: case report with an immunohistochemical analysis. Diagn Pathol. 2013;8:113.
49. Hellquist H, Skalova A. Hybrid tumour. Histopathology of the salivary glands. Heidelberg: Springer; 2014. p. 415-8.

50. Stillwagon GB, Smith RRL, Highstein C, Lee D-J. Adenoid cystic carcinoma of the supraglottic larynx: report of a case and review of the literature. Am J Otolaryngol. 1985;6:309-14. 